\title{
KUALITAS PELAYANAN TERHADAP KEPUASAN PUBLIK DALAM PEMBUATAN KTP DAN KK PADA DINAS KEPENDUDUKAN DAN CATATAN SIPIL KABUPATEN PIDIE
}

\author{
Rozaili \\ Program Studi Administrasi Negara \\ Fakultas Ilmu Administrasi Negara \\ Universitas Jabal Ghafur
}

\begin{abstract}
Location of research "Quality of Service to Public Satisfaction in Making ID Card and Family Card at the Department of Population and Civil Registry of Pidie Regency". Which becomes one of the factors in this context are: 1. How is the quality of service to Public Satisfaction in the Making of KTP and KK at the Department of Population and Civil Registration of Pidie Regency, 2. The factors that become obstacles in providing services to the Public in making ID cards and KK at the Department of Population and Civil Registry of Pidie Regency. The method in this research is qualitative method that is written in the form of descriptive, while this research is research conducted at Department of Population and Civil Registry of Pidie Regency. While the object of research is an employee or government apparatus that provides services to the community in the making of KTP and KK, while the subject of research is the quality of service to the satisfaction of the community in making KTP and KK at the Department of Population and Civil Registry of Pidie District. The sampling technique in this research is using census technique that is all sample population, whereas because many writer take 20 sample people, and that become information in support of the data. KK, and Operator. The results of this study Quality of service to students in the making of ID card and KK at the Department of Population and Civil Registry of Pidie District Taking influence from the level of reliability, the level of responsiveness of employees, direct evidence, the ability of employees, government level, community level, communication level, the quality of service is good, from the level of public satisfaction (community) is the level of fulfillment of needs, achievements, and level of service provided by the Department of Population and Civil Registry of Pidie Regency is satisfied. Factors in providing services to the community who require KTP or KK at the Department of Population and Civil Registration Pidie District is a facility used, no blank ID card for this that comes from Jakarta, human resources are less competent, so many employees who contract employees , building facilities that do not have standards.
\end{abstract}

\section{PENDAHULUAN}

\section{Latar Belakang Masalah}

Pemerintah adalah merupakan sektor pelayanan publik dalam rangka pemenuhan kebutuhan terhadap masyarakat dalam segala bidang, pemerintah yang baik adalah pemerintah yang bebas dari segala penyakit yang dapat melemahkan kinerja pelayanan kepada masyarakat, hal ini bila instansi pemerintah bekerja dengan baik dan akuntabel.

Proses pelayanan pemerintah diserahkan pada instansi unit pelayanan public sesuai dengan peraturan yang berlaku, dimana di tiap department dalam Negara kesatuan republic Indensia sampai kedaerah bahkan desa sekalipun adalah merupakan unsur pelaksanaan pelayanan public yang diserahi tugas menurut wewenang yang ada. Perlayanan yang diberikan adalah melekat pada tugas pokok dan fungsi sebuah lembaga pemerintah maupun swasta, yang kemudian bekerja sesuai dengan petunjuk pelaksanaan dan petunjuk tekniknya..

Negara berkewajiban melayani setiap warga negara dan penduduk untuk memenuhi hak dan kebutuhan dasarnya dalam kerangka pelayanan publik yang merupakan amanat Undang-Undang Dasar Negara Republik Indonesia Tahun 1945, membangun kepercayaan masyarakat atas pelayanan publik yang dilakukan penyelenggara pelayanan publik merupakan kegiatan yang harus dilakukan seiring dengan harapan dan tuntutan seluruh warga negara dan penduduk tentang peningkatan pelayanan publik, sebagai upaya untuk mempertegas hak dan kewajiban setiap warga negara dan penduduk serta terwujudnya tanggung jawab negara dan korporasi dalam penyelenggaraan pelayanan publik, diperlukan norma hukum yang memberi pengaturan secara jelas, sebagai upaya untuk meningkatkan kualitas dan menjamin penyediaan pelayanan 
publik sesuai dengan asas-asas umum pemerintahan dan korporasi yang baik serta untuk memberi perlindungan bagi setiap warga negara dan penduduk dari penyalahgunaan wewenang di dalam penyelenggaraan pelayanan public (Pertimbangan Undang-Undang Republik Indonesia Nomor 25 Tahun 2009 tentang Pelayanan Publik).

Dalam setiap pelaksanaan kegiatan instansi pemerintah seharusnya memberikan kepuasan kepada public (masyarakat) yang diterima dengan memberikan akses seluasluasnya kepada masyarakat yang ingin membutuhkan sesuatu atau keperluan dalam kehidupan mereka, masyarakat sebenarnya tidak menuntut berlebihan dari pemerintah, mereka mengharapkan adanya perhatian instansi pemerintah dalam memenuhi kebutuhan mereka, misal dalam memenuhi kebutuhan Kartu Tanda Penduduk masyarakat, bagaimana pelayanan yang diberikan oleh aparatur pelayanan public yang mereka di gaji oleh Negara untuk memberikan pelayanan kepada nmasyarakat yang sebaik-baiknya. Namun harapan masyarakat belum tercapai sebagaimana yang diinginkan ini disebabkan karena buruknya masih pelayanan instansi birokrasi kita.

Satu hal yang belakangan ini sering dipermasalahkan adalah dalam bidang publik service (Pelayanan Umum), terutama dalam hal kualitas atau mutu pelayanan aparatur pemerintah kepada masyarakat. Pemerintah sebagai service provider (Penyedia Jasa) bagi masyarakat dituntut untuk memberikan pelayanan yang berkualitas. Apalagi pada era otonomi daerah, kulitas dari pelayanan aparatur pemerintah akan semakin ditantang untuk optimal dan mampu menjawab tuntutan yang semakin tinggi dari masyarakat, baik dari segi kulitas maupun dari segi kuantitas pelayanan. Di negara-negara berkembang dapat kita lihat mutu pelayanan publik merupakan masalah yang sering muncul, karena pada negara berkembang umumnya permintaan akan pelayanan jauh melebihi kemampuan pemerintah untuk memenuhinya sehingga pelayanan yang diberikan pemerintah kepada masyarakat kurang terpenuhi baik dilihat dari segi kulitas maupun kuantitas.

Dalam Undang-undang nomor 25 Tahun 2009 tentang Pelayanan Publik pada pasal 1 ayat 1 menyebutkan bahwa pelayanan public adalah kegiatan atau rangkaian kegiatan dalam rangka pemenuhan kebutuhan pelayanan sesuai denganpraturan perundang-undangan bagi setiap warga Negara dan penduduk atas barang, jasa, dan/atau pelayanan administrative yang disediakan oleh penyelenggara pelayanan public.

Dalam hal ini masyarakat adalah seluruh pihak, baik warga Negara maupun penduduk sebagai penerima manfaat pelayanan baik secara langsung maupun tidak langsung. Salah instansi pelayanan public adalah dinas kependudukan dan catatan sipil Kabupaten Pidie sebagai institusi pelayanan kepada masyarakat dalam pembuatan Kartu tanda Penduduk dan Kartu Keluarga adalah pelayanan yang secara langsung kepada masyarakat dalam rangka pemenuhan kebutuhan masyarakat tentang Kartu tanda Penduduk (KTP) dan KK, maka standar pelayan adalah tolok ukur yang digunakan sebagai pedoman penyelenggaraan pelayanan dan acuan penilaian kualitas pelayanan sebagai kewajiban dan janji penyelenggara kepada masyarakat dalam pelayanan yang berkualitas, cepat, mudah, terjangkau dan terukur, maka salah satu acuannya dalam pengukuran pelayanan yang diberikan adalah pada tingkat kepuasan public (masyarakat).

Dalam pemenuhan kebutuihan untuk tercapai kepuasan masyarakat yang dilayaninya tentu saja ada target yang akan dicapai oleh pihak pelayanan itu sendiri, kualitas pelayanan yang ingin dicapai oleh instansi pelayanan public maka sifat atau prinsip dari pada kualitas pelayanan yang perlu dipenuhinya dalam pelayanan itu sendiri, maka dalam penelitian ini focus penelitian adalah pada prinsip kualitas pelayanan seperti kehandalan pegawai dalam memberikan pelayanan, ketanggapan pegawai dalam memberikan pelayanan, bukti langsung, kemampuan mudah diperoleh, keramahan, dapat dipercaya, keamanan, memahami, dan komunikasi, ini merupan prinsip-prinsip dalam kualitas pelayanan yang ada pada suatu institusi pelayanan public dan prinsip ini melekat aparatur pegawai yang memberikan pelayanan.

Dalam melaksanakan prinsip tersebut bila semua terpenuhi apakah penerima layanan dapat memenuhi kebutuhannya, adanya perbedaan, nilai yang dicapai serta keadilan yang diterima 
bila sifat ini dapat diterima atau terpenuhi orang yang dilayaninya, maka kualitas pelayanan pada sebuah instansi public sudah memenuhi standar pelayanan prima

Dari uraian fenomena tersebut,dapat dilihat bahwa pelayanan yang ada pada dinas Kependudukan masih semberawutan, hal ini disebabkan karena tingkat pegawai yang belum mempunyai standar kompetensi yang baik, kemudian system yang dibangun masih sangat rendah serta pengunaan peralatan elektronik yang masih rendah, maka dari kenyataan tersebut, penulis mencoba melihat dari tingkat kualitas pelayanan yang diberikan dengan mengkaji pada tingkat kepuasan public dalam pembuatan KTP dan KK pada Dinas Kependudukan dan Catatan Sipil Kabupaten Pidie dengan mengangkat judul "Kualitas Pelayanan terhadap Kepuasan Publik dalam Pembuatan KTP dan KK pada Dinas Kependudukan dan Catatan Sipil Kabupaten Pidie".

\section{Perumusan masalah}

Adapun yang menjadi permasalahannya di dalam penulisan ini yaitu:

1. Bagaimana kualitas pelayanan terhadap Kepuasan Publik dalam Pembuatan KTP dan KK pada Dinas Kependudukan dan Catatan Sipil Kabupaten Pidie ?

2. Faktor-faktor apakah yang menjadi hambatan dalam memberikan pelayanan kepada Publik dalam Pembuatan KTP dan KK pada Dinas Kependudukan dan Catatan Sipil Kabupaten Pidie?

\section{Tujuan Penulisan} adalah :

Adapun yang menjadi tujuan penulisan ini

1. Untuk mengetahui kualitas pelayanan terhadap Kepuasan Publik dalam Pembuatan KTP dan KK pada Dinas Kependudukan dan Catatan Sipil Kabupaten Pidie.

2. Untuk mengetahui Faktor-faktor yang menjadi hambatan dalam memberikan pelayanan kepada Publik dalam Pembuatan KTP dan KK pada Dinas Kependudukan dan Catatan Sipil Kabupaten Pidie.

\section{STUDI KEPUSTAKAAN \\ Pelayanan Publik.}

Pelayanan publik atau pelayanan umum dapat didefinisikan sebagai segala bentuk jasa pelayanan, baik dalam bentuk barang publik maupun jasa publik yang pada prinsipnya menjadi tanggung jawab dan dilaksanakan oleh Instansi Pemerintah di Pusat, di Daerah, dan di lingkungan Badan Usaha Milik Negara atau Badan Usaha Milik Daerah, dalam rangka upaya pemenuhan kebutuhan masyarakat maupun dalam rangka pelaksanaan ketentuan peraturan perundang-undangan.

Undang-Undang Pelayanan Publik (secara resmi bernama Undang-Undang Nomor 25 Tahun 2009 tentang Pelayanan Publik) adalah undang-undang yang mengatur tentang prinsipprinsip pemerintahan yang baik yang merupakan efektifitas fungsi-fungsi pemerintahan itu sendiri. perlayanan publik yang dilakukan oleh pemerintahan atau koporasi yang efektif dapat memperkuat demokrasi dan hak asasi manusia, mempromosikan kemakmuran ekonomi, kohesi sosial, mengurangi kemiskinan, meningkatkan perlindungan lingkungan, bijak dalam pemanfaatan sumber daya alam, memperdalam kepercayaan pada pemerintahan dan administrasi publik.

Pembina dalam penyelenggaraan pelayanan publik dilakukan oleh pimpinan lembaga negara, pimpinan kementerian, pimpinan lembaga pemerintah nonkementerian, pimpinan lembaga komisi negara atau yang sejenis, dan pimpinan lembaga lainnya terhadap pimpinan lembaga negara dan pimpinan lembaga komisi negara atau yang sejenis yang dibentuk berdasarkan undang-undang, gubernur pada tingkat provinsi melaporkan hasil perkembangan kinerja pelayanan publik masingmasing kepada dewan perwakilan rakyat daerah provinsi dan menteri dan bupati pada tingkat kabupaten beserta walikota pada tingkat kota wajib melaporkan hasil perkembangan kinerja pelayanan publik masing-masing kepada dewan perwakilan rakyat daerah kabupaten/kota dan gubernur dan penanggung jawab mempunyai tugas untuk mengoordinasikan kelancaran penyelenggaraan pelayanan publik sesuai dengan standar pelayanan pada setiap satuan kerja, melakukan evaluasi penyelenggaraan pelayanan publik dan melaporkan kepada pembina pelaksanaan penyelenggaraan pelayanan publik di seluruh satuan kerja unit pelayanan publik, Menteri yang bertanggung jawab di bidang pendayagunaan aparatur negara 
bertugas merumuskan kebijakan nasional tentang pelayanan publik, memfasilitasi lembaga terkait untuk menyelesaikan permasalahan yang terjadi antarpenyelenggara yang tidak dapat diselesaikan dengan mekanisme yang ada, melakukan pemantauan dan evaluasi kinerja penyelenggaraan pelayanan publik dengan mengumumkan kebijakan nasional tentang pelayanan publik atas hasil pemantauan dan evaluasi kinerja, serta hasil koordinasi, membuat peringkat kinerja penyelenggara secara berkala; dan dapat memberikan penghargaan kepada penyelenggara dan penyelenggara dan seluruh bagian organisasi penyelenggara bertanggung jawab atas ketidakmampuan, pelanggaran, dan kegagalan penyelenggaraan pelayanan (UU PelayananPublik Nomor 25 Tahun 2009).

\section{Kepuasan Publik.}

Kepuasan adalah tingkat perasaan seseorang setelah membandingkan kinerja/hasil yang dirasakannya dengan harapannya. Sedangkan menurut Kotler (2009: 42) mengatakan bahwa kepuasan adalah perasaan senang atau kecewa seseorang yang muncul setelah membandingkan antara persepsi/kesannya terhadap kinerja atau hasil suatu produk atau jasa dan harapan-harapannya. Untuk menciptakan kepuasan pelanggan, perusahaan harus menciptakan dan mengelola suatu sistem untuk memperoleh pelanggan yang lebih banyak dan kemampuan untuk mempertankan pelanggannya.

Menurut tiori kepuasan dua faktor utama yang merupakan kepuasan yang mengajurkan bahwa satisfaction (kepuasan) dan dissatisfaction (ketidak puasan) merupakan bagian dari kelompok variabel yang berbeda, yaitu motivasi dan hygiene factors. Pada umumnya orang mengharapkan bahwa faktor tertentu memberikan kepuasan apabila tersedia dan menimbulkan ketidakpuasan apabila tidak ada, ketidakpuasan dihubungkan dengan kondisi di sekitarnya.

Menurut Kreitner dan Kinicki (2008: 225) terdapat lima faktor yang dapat menimbulkan kepuasan, yaitu sebagai berikut:

1. Need Fulfillment (pemenuhan kebutuhan). Model ini dimaksudkan bahwa kepuasan ditentukan oleh tingkatan karakteristik memberikan kesempatan pada individu untuk memenuhi kebutuhan.

2. Discrepancies (perbedaan). Bahwa kepuasan merupakan suatu hasil memenuhi harapakan. Pemenuhan harapan mencerminkan perbedaan antara apa yang diharapkan dan yang diperoleh individu, apabila harapan lebih besar daripada apa yang diterima orang akan tidak puas, dan sebaliknya diperkirakan individu akan puas apabila mareka menerima manfaat di atas harapan.

3. Value Attainment (pencapaian nilai). Gagasan ini adalah bahwa kepuasan merupakan hasil dari persepsi pekerjaan memberikan pemenuhan nilai individu yang penting.

4. Equity (keadilan), bahwa kepuasan merupakan fungsi dari seberapa adil individu diperlakukan, kepuasan merupakan hasil dari persepsi orang bahwa perbandingan antara hasil kerja dan inputnya relative lebih menguntungkan dibandingkan dengan perbandingan antara keluaran dan masukan lainnya.

5. Disposition/genetic component (komponen genetic), kebanyak orang kan puas terhadap lingkungan, sedangkan lainnya kelihatan tidak puas. Model ini didasarkan pada kenyakinan bahwa kepuasan sebagian merupakan fungsi sifat pribadi dan faktor genetic.

Menurut Kotler (2009:36), kepuasan adalah perasaan senang atau kecewa seseorang yang berasal dari perbandingan antara kesannya terhadap kinerja (atau hasil) suatu produk dan harapan-harapannya.

\section{Mengukur Kepuasan Publik.}

Kepuasan pelanggan merupakan suatu usaha perusahaan yang dilakukan dalam pengembangan perusahaan dan memberikan keinginan pelanggan agar pelanggan menjadi betah dan terikat dengan keinginan perusahaan. Kepuasan pelanggan adalah suatu keadaan di mana keinginan, harapan dan kebutuhan pelanggan dipenuhi, suatu pelayanan dinilai memuaskan bila pelayanan tersebut dapat memenuhi kebutuhan dan harapan pelanggan. 
Tingkat kepuasan pelanggan terhadap pelayanan merupakan faktor yang penting dalam mengembangkan suatu sistem penyediaan pelayanan yang tanggap terhadap kebutuhankebutuhan pelanggan, meminimalkan biaya dan waktu serta memaksimalkan dampak pelayanan terhadap populasi sasaran. Oleh karena pendekatan partisifatif diperlukan di dalam pengumpulan data. Pengukuran kepuasan pelanggan merupakan elemen penting dalam menyediakan pelayanan yang lebih baik, lebih efektif dan lebih efesien. Apabila pelanggan merasa tidak puas terhadap suatu pelayanan yang disediakan, maka pelayanan tersebut dapat dipastikan tidak efektif dan tidak efeksien.

Biasanya cara yang sangat sederhana dalam mengukur kepuasan pelanggan antara lain adalah :

1. Sistem keluhan dan saran. Industri yang berwawasan pelanggan akan menyediakan formulasi bagi pelanggan untuk melaporkan kesukaran dan keluhannya. Selain itu dapat berupa kotak saran dan telepon pengaduan bagi pelanggan.

2. Survey kepuasan pelanggan. Industri tidak dapat menggunakan tingkat keluhan sebagai ukuran kepuasan pelanggan. Perusahaan yang responsive mengukur kepuasan pelanggan dengan mengadakan survei berskala, yaitu dengan mengirimkan daftar pertanyaan atau menelpon secara acak dari pelanggan untuk mengetahui perasaan mareka terhadap berbagai kinerja perusahaan, dan juga tentang kinerja perusahaan saingan.

3. Ghost Shopping (pelanggan Banyangan). Pelanggan banyangan adalah menyuruh orang berpura-pura menjadi pelanggan dan melaporkan titik-titik kuat maupun lemah yang dialami waktu membeli produk dari perusahaan sendiri maupun saingannya.

4. Analisa pelanggan yang beralih. Industri dapat menghubungkan pelanggan yang tidak membeli lagi atau berganti pemasok untuk mengetahui penyebabnya, apakah harganya tinggi, pelayanan kurang baik, produknya kurang dapat diandalkan dan seterusnya, sehingga dapat diketahui tingkat kehilangan pelanggan.
Dalam keputusan Menteri Pendayagunaan Aparatur Negara Nomor Kep/25/M.PAN/2/2004, tentang Pedoman Umum Penyusunan Indek Kepuasan Masyarakat Unit Pelayanan Instansi Pemerintah salah satu upaya untuk meningkatkan kualitas pelayanan public, sebagaimana diamanatkan dalam Undang-Undang Republik Indonesia Nomor 25 Tahun 2000 Tentang pProgram Pembangunan Nasional (PROPENAS), perlu disusun indeks kepuasan masyarakat sebagaimana tolok ukur untuk menilai tingkat kualitas pelayanan.

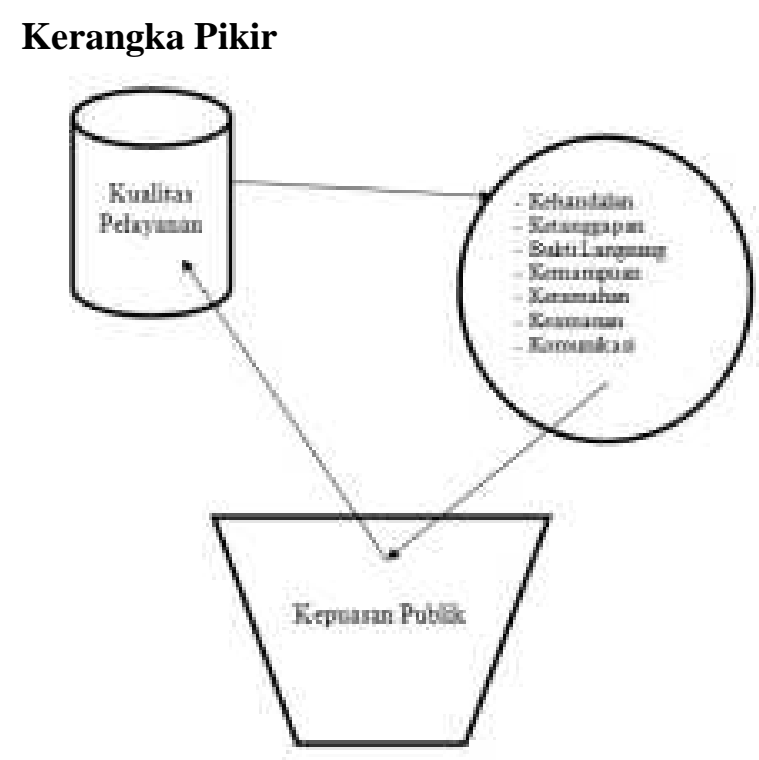

Sumber :Teori dikembangkan 2017

\section{METODE PENELITIAN \\ Metode dan Objek Penelitian.}

Metode dalam penelitian ini adalah memakai metode kualitatif sedangkan penulisannya berbentuk deskriptif, sedangkan lokasi penelitian adalah tempat dimana penulis melakukan serangkaian penelitian pada Dinas Kependudukan dan Catatan Sipil Kabupaten Pidie. Sedangkan objek penelitian adalah karyawan atau aparatur pemerintah yang bertugas memberikan pelayanan kepada masyarakat dalampembuatan KTP dan KK, sedangkan subjek penelitian adalah kualitas pelayanan terhadap kepuasan publik dalam pembuatan KTP dan KK pada Dinas Kependudukan dan Catatan Sipil Kabupaten Pidie. 


\section{Populasi dan Sampel Penelitian \\ Populasi Penelitian}

Populasi adalah keseluruhan jumlah yang terdiri atas objek atau subjek yang mempunyai karakteristik dan kualitas tertentu yang ditetapkan oleh peneliti untuk diteliti dan kemudian ditarik suatu kesimpulan, (Sujarweni, 2014: 65). Besarnya populasi mempengaruhi representativ sampel, karena makin besar jumlah sampel maka besar peluang sampel mengikuti ciri-ciri dan distribusi populasi, ketentuan tersebut memang memilki batasan (yaitu pada populasi yang tidak homogen) karena pada populasi homogeny sempurna besarnya jumlah sampel tidak berpengaruh pada tingkat representative sampel (Nyoman, 2012:38), jadi populasi dalam penelitian ini adalah sejumlah sejumlah masyarakat yang ingin membuat KTP dan KK pada Dinas Kependudukan dan Catatan Sipil Kabupaten Pidie dengan cara mengajukan pertanyaan.

\section{Sampel Penelitian.}

Populasinya tidak menetap atau dinamis dan tidak menentu serta bervariasi, maka tidak semua populasi dijadikan sampel dimana pengambilan sampel dilakukan dengan memakai teknik Nonprobability sampling adalah pengambilan sampel yang memberikan peluang yang sama bagi setiap unsur populasi untuk dipilih menjadi anggota sampel (Sujarweni, 2014: 69).

Teknik pengambilan sampel dalam penelitian ini adalah menggunakan teknik sensus adalah semua populasi dijadikan sampel, maka karena populasi terlau banyak penulis mengambil 20 orang sampel, dan yang menjadi informen dalam mendukung data penelitian ini adalah Kepala Dinas, Kepala Bagian KTP dan KK, Kasi Bagian KTP dan KK, dan Operator.

\section{Teknik Pengumpulan Data.}

Untuk dapat memperoleh data yang akurat dan relevan dalam penelitian ini, dilaksanakan serangkaian data yaitu untuk melengkapi semua data yang diperlukan dalam penulisan karya akhir ini penulis mendapatkan data-data dari Dinas Kependudukan dan Catatan Sipil Kabupaten Pidie dengan teknik wawancara dan pada masyarakat yang membuat KTP dan KK dengan teknik pendekatan Kuesioner, yaitu suatu teknik pengumpulan data dengan mengajukan sejumlah pertanyaan dalam bentuk tertulis kepada sejumlah responden.

Teknik pengumpulan data dalam penelitian ini adalah menggunakan data primer dan data sekunder. Data primer diperoleh melalui wawancara secara langsung dengan para objek penelitian yang diplih sebagai responden dengan menggunakan lembaran kuesioner, sedangkan data sekunder diperoleh dari buku-buku bacaan, majalah-majalah dan juga dari sumber-sumber lainnya yang sesuai dengan objek penelitian, atau lebih lengkapnya penulis memperoleh data dalam penelitian ini dengan menggunakan metode dan teknik yaitu :

1. Penelitian Perpustakaan (Library Research); Metode pengumpulan data dengan mengutip hasil dari sejumlah buku dan pendapat para ahli yang ada hubungannya dengan topik penelitian ini.

2. Penelitian Lapangan (Field Research); Metode ini adalah untuk mendapatkan data yang ada di lokasi penelitian, dalam penelitian ini penulis menggunakan teknik atau instrument yang sebagai berikut:

a. Wawancara (Interview). Wawancara adalah suatu teknik penelitian dengan cara melakukan serangkaian interview secara tatap muka dengan para pemberi informasi (objek penelitian) yaitu terutama dengan orang yang memiliki kaitan dengan penelitian ini.

b. Observasi atau pengamatan adalah suatu teknik pengumpulan data dengan cara melihat dan mengamati secara langsung dari dekat tentang aktivitas ditempat penelitian.

c. Kuesioner yaitu dengan mengajukan pertanyaan-pertanyaan yang dijawab oleh koresponden, merupakan data awal dari sebuah penelitian.

\section{Analisis Data.}

Data yang telah dikumpulkan akan dianalisis dengan pendekatan kualitatif model 
interaktif, yaitu terdiri dari tiga hal utama yaitu reduksi data, penyajian data, dan penarikan kesimpula/verivikasi sebagai sesuatu yang jalinmenjalin pada saat sebelumnya, selama, dan sesudah pengumpulan data dalam bentuk yang sejajar, untuk membangun wawasan umum yang disebut analisis (Miles dan Huberman dalam Idrus, 2009: 246).

Dalam sugiyono (2016: 247) yaitu analisis interaktif dengan langkah-langkah sebagai berikut

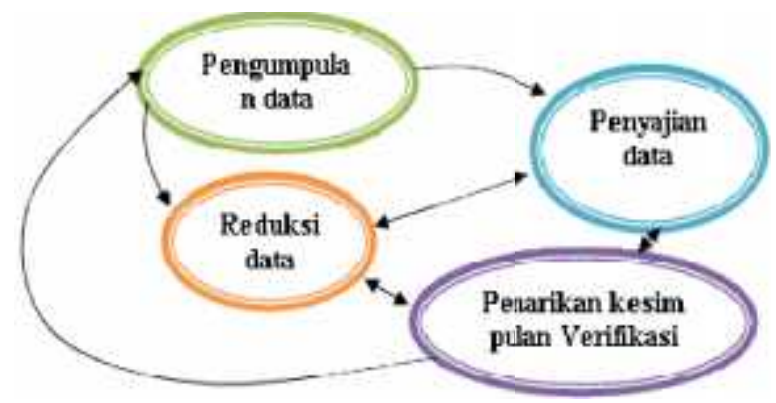

Sumber :Analisis Data Kualitatif Miles dan Huberman

Gambar 1 : Analisa Interaktif dari Miles dan Huberman dalam Sugiyono (2016: 247)

1. Tahap pengumpulan data dilakukan dengan fenomena, sikap dan perilaku sehari-hari dari informan yang diperoleh dari hasil observasi mereka dengan menggunakan beberpa teknik seperti wawancara dan dokumentasi sebagaimana telah dijelaskan dimuka dari penulisan proposal penelitian ini, data yang dikumpulkan adalah data dari informan yaitu pengawasan sekolah, kepala sekolah dan bebera guru yang terlibat langsung dengan masalah yang diteliti data yang dikumpulkan berupa dokumen dari hasil pelaksanaan strategi pengembangan professional kepala sekolah.

2. Tahap Reduksi Data (data reduction); sehubungan data yang diperoleh dilapangan terlalu banyak, maka tersebut perlu di catat secara teliti dan cermat. Reduksi data dapat diartikan sebagai proses pemilihan, pemusatan perhatian pada penyederhanaan, pengabstrakan, dan transformasi data kasar yang muncul dari catatan-catatan tertulis dari lapangan.

3. Tahap penyajian data: penyajian data dilakukan adalah untuk memudahkan bagi peneliti untuk melihat gambaran secara keseluruhan atau bagian-bagian penting yang diteliti. Menurut Miles dan Huberman dalam Idrus (2009: 151) menyebutkan bahwa sebagai sekumpulan informasi tersusun yang member kemungkinan adanya penarikan kesimpulan dan pengambilan tindakan. Dengan adanya penyajian data tersebut peneliti lebih mudah memahami apa yang sedang terjadi dan apa yang harus dilakukan, maka peneliti dalam penyajian data dalam penelitian ini akan disajikan data dalam bentuk tabel-tabel dan uraian naratif.

4. Tahap verifikasi dan Penarikan Kesimpulan; adalah tahap akhir proses pengumpulan data yang dilakukan secara terus menerus sepanjang proses penelitian ini dilakukan sejak awal memasuki lapangan dan selama prose pengumpulan data dilakukan. Menurut Miles dalam Idrus (2009: 151) menyataan bahwa dari permulaan pengumpulan data, seorang penganalisis kualitatif mulai mencari arti benda-benda, mencatat keteraturan, polapola penjelasan, konfigurasi-konfigurasi yang mungkin ada, alur sebab akibat, dan proposinya.

\section{PENELITIAN DAN PEMBAHASAN \\ Gambaran Umum Objek Penelitian.}

Objek penelitian adalah lokasi penelitian yang dilakukan, dimana lokasi penelitian dalam penelitian ini adalah pada Dinas Kependudukan dan Catatan Sipil Kabupaten Pidie, maka yang menjadi objek penelitian adalah melihat kualitas pelayanan terhadap kepuasan public dalam pembuatan KTP dan KK yang merupakan tugas pokok Dinas Kependudukan dan Catatan Sipil Kabupaten Pidie sebagai pelayanan public sebagaimana yang telah disusun dalam Peraturan Bupati Pidie nomor 12 tahun 2017 tentang Kedudukan, Susunan Organisasi, Tugas, Fungsi dan Tata Kerja Dinas Kependudukan dan Pencatatan Sipil Kabupaten Pidie.

Dalam Peraturan Bupati Pidie pada pasal 4 menyebutkan bahwa:

1. Dinas Kependudukan dan Pencatatan Sipil merupakan unsur pelaksanaan urusan pemerintahan bidang Kependudukan dan Pencatatan Sipil yang menjadi kewenangannya;

2. Dinas Kependudukan dan Pencatatan Sipil dipimpin oleh Kepala Dinas yang berkedudukan di bawah dan bertanggung jawab kepada Bupati melalui Sekda; 
3. Sekretariat dipimpin oleh seorang Sekretaris yang berada di bawah dan bertanggung jawab kepada Kepala Dinas;

4. Bidang dipimpin oleh seorang Kepala Badang yang berada di bawah dan bertanggung jawab kepada Kepala Dinas;

5. Sub Bagian dipimpin oleh seorang Kepala Sub Bagian yang berada di bawah dan bertanggung jawab kepada Sekretaris;

6. Seksi dipimpin oleh Kepala Seksi yang berada di bawah dan bertanggung jawab kepada Kepala Bidang;

Dalam pelaksanaan tugas sebagai pelayanan kepada masyarakat dalam pembuatan KTP, KK dan lain sebagainya tidak terlepas pada apa yang telah diatur melalu peraturan perundang undangan yang berlaku sebagaimana tugas dan kedudukannya pasal 5 menyebutkan bahwa "Dinas Kependudukan dan Catatan Sipil mempunyai tugas membantu Bupati melaksanakan urusan pemerintahan bidang Kependudukan dan Catatan Sipil dan urusan tugas pembantuan yang diberikan kepala daerah".

Dinas Kependudukan dan Catatan Sipil dalam melaksanakan tugas sebagaimana dimaksud dalam pasal 5, menyelenggarakan fungsinya:

1. perumusan kebijakan di bidang Kependudukan dan Pencatatan Sipil;

2. Pelaksanaan kebijakan di bidang Kependudukan dan Catatan Sipil;

3. Pelaksanaan evaluasi dan pelaporan di bidang Kependudukan dan Catatan Sipil;

4. Pelaksanaan administrasi dinas sesuai dengan lingkup tugasnya; dan

5. Pelaksanaan fungsi lain yang diberikan oleh Bupati terkait dengan tugas dan fungsinya;

Dalam pelaksanaan tugasnya Dinas Kependudukan dan Catatan Sipil Kabupaten Pidie pelayanan secara teknis yang merupakan tugasnya dilaksanakan oleh bidang-bidang teknis dalam pelayanan kepada masyarakat sebagaimana system dan mekanisme sesuai dengan standar operasional prosedur pelayanan yang telah ditetapkan.

Standar operasional Prosedur pelayanan adalah sebagaimana mekanisme pengurusan pembuatan KTP dan KK tentu saja melalui suatu system berjenjang dari keuchik sampai kepada Dinas Kependudukan dan Catatan Sipil, karena dalam pelaksanaan pembuatan KTP dan KK pada Dinas Kependudukan dan Catatan Sipil Kabupaten Pidie sudah dilakukan melalui suatu system yang terintegrasi dalam sebuah server berhubungan langsung dengan Kementrian Dalam Negeri. Pada bidang pelayanan pendaftaran penduduk dalam melaksanakan tugasnya sebagaimana dimaksud dalam pasal 10 Peraturan Bupati Pidie nomor 12 tahun 2017, menyelenggarakan fungsinya adalah sebagai berikut:

1. Penyusunan perencanaan pelayanan pendaftaran penduduk;

2. perumusan kebijakan teknis pendaftaran penduduk;

3. pelaksanaan pembinaan dan koordinasi pelaksanaan pelayanan pendaftaran penduduk;

4. pelaksanaan pelayanan pendaftaran penduduk;

5. pelaksanaan penerbitan dokumen pendaftaran penduduk;

6. pelaksanaan pedokumentasian hasil pelayanan pendaftaran penduduk;

7. pengendalian dan evaluasi pelaksanaan pendaftaran penduduk;

8. pelaksanaan tugas-tugas kedinasan lainnya yang diberikan oleh Kepala dinas sesuai dengan tugas dan fungsinya;

Dalam melaksanakan setiap fungsinya sebagaimana yang telahdilimpahkan dalam pelayanan kepada masyarakat Dinas Kependudukan dan Catatan Sipil didukung oleh perangkat yang memadai atau sarana dan prasarana yang memadai, dari observasi yang dilakukan dilapangan bahwa sarana kantor yang belum memadai, karena kantor jauh dari sebuah kantor dalam melakukan pelayanan public, dengan beban pekerjaan yang banyak sementara kantor sempit dan tidak sesuai dengan harapan dan kenyamanan pegawai dalam melakukan aktivitas pelayanan.

Perekaman dokumen yang dilakukan dalam pembuatan KTP dan KK dilakuakn dengan menggunakan suatu perangkat IT (perangkat computer) yang telah terkoneksi dengan Kementerian Dalam Negeri adalah sudah sesuai dengan standar kerja, perangkatnya sudah baik perlu penambahan computer agar pelayanan yang diberikan oleh pegawai Dinas Kependudukan dan Catatan Sipil lebih cepat lag, masyarakat tidak lama-lama menunggu dalam membuat proses pembuatan KTP dan KK.

Sarana dan Prasarana yang mendukung dalam proses pelayanan pembuatan KTP dan KK sebagaimana terliat dalam tabel berikut ini; 
TABEL 4-1

KEADAAN SARANA DAN PRASANA PADA DINAS KEPENDUDUKAN DAN CATATAN SIPIL

\begin{tabular}{|c|c|c|c|}
\hline No & Jenis & Jurulath & Keterangar \\
\hline 1. & Gedung & 1 unit & Kecil \\
\hline 2 & Komputer & 12. Ir ir & Raik \\
\hline 3. & Mobil & I unit & Baik \\
\hline 4. & Sepecia motor & 4 unit & Baik \\
\hline 5. & Mosit KTF Keliling & I unit & Baik \\
\hline o. & Perangkat Sistem & L unit & batk \\
\hline
\end{tabular}

Sumber: Data Dinas Kependudukan dan Catatan Sipil 2017.

Dari tabel tersebut di atas maka dapat dilihat bahwa untuk sarana dan prasarana dalam mendukung pelayanan public sudah memadai kecuali perangkat computer yang perlu penambahan dan perbaikan, sementara untuk gedung tentu saja dengan pekerjaan yang banyak tidak memadai gedung yag demikian kecil.

Sementara untuk personil atau pegawai dalam memberikan pelayanan berjumlah 31 orang sebagaimana komposisi dapat dilihat pada tabel berikut ini:

TABEL 4-2

TINGKAT PENDIDIKAN PEGAWAI

\begin{tabular}{|c|l|c|c|}
\hline No & Tingkat Pendidikan & Jumlah & $\%$ \\
\hline 1. & S2 & 3 & 9.7 \\
2. & S1 & 19 & 61.3 \\
3. & D3 & - & \\
4. & SLTA & 9 & 29.0 \\
5 & SLTP & - & - \\
\hline \multicolumn{2}{|c|}{ Jumlah } & 31 & 100.0 \\
\hline
\end{tabular}

Sumber: Data Dinas Kependudukan dan Catatan Sipil 2017.

Dari tabel tersebut di atas, maka tingkat pendidikan pegawai pada Dinas Kependudukan dan Catatan Sipil adalah di dominasi oleh S1 atau tingkat sarjana, maka dengan demikian dilihat dari kompetensi pegawai pelayanan sudah menunjukan untuk memberikan pelayanan yang baik.

Perbandingan jumlah pegawai pada Dinas Kependudukan dan Catatan Sipil antara jumlah pegawai laki-laki dengan pegawai perempuan bahwa perbandingan jumlah pegawai laki-laki berjumlah 17 orang atau $54.8 \%$ sedangkan pegawai perempuan berjumlah 14 orang atau berjumlah $45.2 \%$, maka jumlah pegawai lakilaki lebih dominan dari pada pegawai perempuan sebagai mana dilihat pada tabel dibawah ini;

TABEL 4-3

TINGKAT JUMLAH PEGAWAI

\begin{tabular}{|c|l|c|c|}
\hline No & Jenis Kelamin & Jumlah & $\%$ \\
\hline 1. & Laki-laki & 17 & 54.8 \\
2. & Perempuan & 14 & 45.2 \\
\hline \multicolumn{2}{|c|}{ Jumlah } & 31 & \\
\hline
\end{tabular}

Sumber: Data Dinas Kependudukan dan Catatan Sipil 2017.

Dalam pelayanan yang agar tercapai kepuasan masyarakat sebegai penerima manfaat dari pelayanan yang diberikan pemerintah tentu saja setiap pelayanan jasa mempunya kualitas pelayanan itu sendiri, Pemerintah selaku penyedian pelayanaan birokrasi pemerintahan kepada masyarakat secara menyeluruh, baik pada level kebijakan, organizational, serta operasional harus sesuai dengan dengan poinpoin mendasar dalam Undang-undang No. 25 Tahun 2009 tentang Pelayanan Publik. Pada level kebijakan, dalam bentuk peraturan atau kebijakan yang mengatur seluruh aspek sehingga menciptakan berbagai peraturan atau kebijakan yang mendorong birokrasi yang berorientasi pada pemenuhan hal-hak sipil warga negara dalam mendapatkan pelayanan prima yang yang di dalamnya menyangkut aspek kepastian hukum, batas waktu, prosedur, partisipasi, pengaduan, dan gugatan.

Penyusunan Standar Prosedur Operasi (SOP) pada Dinas Kependudukan dan Catatan Sipil dalam memberikan pelayanan kepada masyarakat. Sebagai organisasi yang pro publik, penyempurnaan diarahkan untuk menghasilkan proses yang akuntabel dan transparan, serta mempunyai kinerja yang cepat dan ringkas. Untuk itu, penyusun SOP yang rinci dan dapat menggambarkan setiap jenis keluaran pekerjaan secara menyeluruh, melakukan analisis dan evaluasi jabatan untuk memperoleh gambaran rinci mengenai tugas yang dilakukan oleh setiap jabatan, serta melakukan analisis beban kerja untuk dapat memperoleh informasi mengenai waktu dan jumlah pejabat yang dibutuhkan untuk melaksanakan suatu pekerjaan. Dengan adanya standar prosedur operasi tersebut instasi pemerintah dapat memberikan layanan prima kepada publik, yaitu layanan yang terukur dan pasti dalam hal waktu penyelesaian, persyaratan administrasi yang harus dipenuhi, dan biaya yang harus dikeluarkan. 
Maka dari hasil wawancara dengan Sekretaris Dinas Kependudukan dan Catatan Sipil menyatakan bahwa;

Sebenarnya dalam pelayanan yang dilakukan oleh pegawai pada Dinas Kependudukan dan Catatan Sipil berpedoman pada petunjuk teknis dan petunjuk pelaksanaan yang telah dituangkan dalam Standar Operasional Pelayanan, maka masyarakat yang membutuhkan pelayanan untuk membuat KTP dan KK yang datang kekantor baik yang jauh dengan yang dekat dalam menerima pelayanan sama karena mengikuti alur pelayanan dari pengambilan nomor antri sampai pembuatan KTP atau KK selesai dan juga Dinas Kependudukan dan Catatan Sipil dalam memberikan pelayanan mengikuti prinsipprinsip kualitas pelayanan seperti adanya akuntabel, realibilitas dan adanya jaminan, maka masyarakat yang datang untuk membuat KTP dan KK membawa berkas da langsung bisa dip roses, dan bila bahan belum lengkap pegawai dengan baik untuk bisa dikembalikan besok".

Pada level organisasi yaitu Dinas Kependudukan dan Catatan Sipil, dapat dilakukan dalam bentuk perbaikan proses rekrutmen berbasis kompetensi, pendidikan dan latihan yang sensitif terhadap kepentingan masyarakat, penciptaan Standar Kinerja Individu, Standar Kinerja Tim dan Standar Kinerja Instansi Pemerintah. Memulai proses organization reinventing dalam bentuk penataan organisasi. Penataan organisasi tersebut meliputi pemisahan, penggabungan, dan penajaman fungsi, serta modernisasi. Penajaman tugas dan fungsi dilakukan di segala level pemerintahan baik dari pusat sampai ke level pemerintahan pada level terbawah. Disamping itu, dilakukan pemisahan dan penajaman fungsi organisasi yang diharapkan mampu menciptakan struktur organisasi yang menghasilkan kebijakan berkualitas dan dapat memberikan pelayanan terbaik kepada masyarakat. maka Dinas Kependudukan dan Catatan Sipil disamping pegawai tetap yaitu Pegawai Negeri Sipil (PNS) ada pegawai kontrak yang direkrut berdasarkan kompetensi dalam operator (user) dalam memberikan pelayanan mereka merupakan leval operasional.

Terakhir pada level operasional, dilakukan melalui perbaikan serta peningkatan kualitas pelayanan yang meliputi dimensi tangibles, reliability, responsiveness, assurance dan emphaty. Perbaikan pelayanan kepada masyarakat tersebut salah satunya tercermin dalam adanya perubahan waktu yang diperlukan masyarakat untuk mendapatkan layanan.
Selanjutnya, pelayanan publik yang dilakukan pemerintah juga dilihat dari segi faktor-faktor yang mempengaruhi birokrasi haruslah dilakukan perubahan, diantaranya adalah faktor budaya, faktor individu, faktor organisasi dan manajemen, serta faktor politik. Sehingga institusi pemerintahan dapat berjalan sebagaimana mestinya sesuai dengan amanat UU No. 25 Tahun 2009.

\section{Karakteristik Responden.}

Responden adalah sejumlah orang atau objek yang menjadi informen dalam sebuah penelitian, untuk lebih kompetitif dalam sebuah penelitian maka peneliti mengetahui karakteristik responden, karena akan mempengaruhi terhadap sejumlah jawaban yang diberikan, maka dalam hal ini responden dalam penelitian ini karena melihat perilaku dalam pelayanan public, maka karakteristik responden adalah sejumlah masyarakat yang sedang membuat KTP dan KK pada maka Dinas Kependudukan dan Catatan Sipil yang diambil secara kebutulan, maka pengambila data dengan menyiapkan angket serta wawancara untuk mendapatkan data dalam penelitian ini.

Maka penulis akan mengambil semua pegawai menjadi responden sebagaimana karakteristik terlihat pada tabel dibawah ini:

TABEL 4-4 KARAKTERISTIK RESPONDEN

\begin{tabular}{|c|c|c|c|}
\hline No & Uraian & $\begin{array}{c}\text { Frekw } \\
\text { ensi }\end{array}$ & $\begin{array}{l}\text { Persenta } \\
\text { se }\end{array}$ \\
\hline 1. & $\begin{array}{l}\text { Jenis Kelamin } \\
\text { - Laki-laki } \\
\text { - Perempuan }\end{array}$ & $\begin{array}{c}12 \\
8\end{array}$ & $\begin{array}{l}60.0 \\
40.0\end{array}$ \\
\hline 3. & $\begin{array}{l}\text { Pendidikan terakhir } \\
\text { - SLTP } \\
\text { - SLTA } \\
\text { - Diploma/D3 } \\
\text { - Sarjana }\end{array}$ & $\begin{array}{c}3 \\
10 \\
2 \\
5\end{array}$ & $\begin{array}{l}15.0 \\
50.0 \\
10.0 \\
25.0\end{array}$ \\
\hline 4. & $\begin{array}{l}\text { Umur } \\
\text { - 20-29 tahun } \\
\text { - } 30-39 \text { tahun } \\
\text { - 40-49 tahun } \\
\text { - } 50 \text { keatas }\end{array}$ & $\begin{array}{c}1 \\
4 \\
11 \\
4\end{array}$ & $\begin{array}{c}5.0 \\
20.0 \\
55.0 \\
20.0\end{array}$ \\
\hline & Jumlah & 20 & $100.0 \%$ \\
\hline
\end{tabular}

Sumber : data primer (diolah), 2017.

Dilihat dari tabel tersebut diatas dapat dijelaskan bahwa yang menjadi karakteristik dari pada penelitian ini adalah jumlah 
responden (masyarakat) yang pada saat itu datang kepada Dinas Kependudukan dan Catatan Sipil untuk membuat KTP dan KK, maka untuk memperoleh data penulis mengisi angket yang telah disipakan dan dengan wawancara yang dilakukan untuk mendapatkan data secara mendetil dalam penulisan ini.

Responden yang menjadi karakteristik dilihat dari jenis kelamin laki-laki berjumlah 12 orang atau $60.0 \%$ sedangkan responden perempuan berjumlah 8 atau $40.0 . \%$, dilihat dari pada tingkat pendidikan responden adalah tingkat pendidikan responden dengan pendidikan SLTP berjumlah 3 orang atau 15.0\%, tingkat pendidikan SLTA sejumlah 10 orang atau $50.0 \%$, responden yang pendidikannya tingkat diploma berjumlah 2 orang atau setara dengan $10.0 \%$ dan responden yang tingkat berpendidikan sarjana sejumlah 5 orang atau $25.0 \%$.

Tingkat umur responden adalah yang usia 20 sampai dengan 29 tahun adalah 1 orang atau $5.0 \%$, usia responden 30 sampai dengan 39 tahun berjumlah 4 orang atau $20.0 \%$, sedangkan usia responden 40 sampai dengan 49 tahun berjumlah 11 orang atau $55.0 \%$, sedangkan tingkat usai responden 50 tahun keatas adalah 4 orang atau $20.0 \%$.

Dari hasil yang dilihat terhadap karakteristik responden adalah sangat berpengaruh terhadap data yang didapatkan atau tingkat kenyakinannya sebuah data hari.

\section{Pembahasan Kualitas Pelayanan Terhadap Kepuasan Publik. \\ Tingkat Keandalan (reliability) Pegawai.}

Tingkat kehandalan atau dengan bahasa lain reliability kemampuan untuk melaksanakan jasa yang dijanjikan dengan tepat dan terpecaya, kehandalan yang diukur dalam penelitian ini adalah kemapuan seorang pegawai untuk melaksanakan jasa yang dijanjikan engan tepat dan terpecaya, seorang pegawai bagaimana melakukan pelayanan pada pembuatan KTP dan KK pada Dinas Kependudukan dan Catatan Sipil dengan tingkat kompetensi yang dimiliki oleh pegawai baik kemampuan dasar maupun kemampuan yang didapatkan dalam pengalaman kerja atau pelatihan-pelatihan yang pernah diikuti, maka pertanyaan yang diajukan pada responden adalah bagaimana tingkak kemampuan pegawai dalam melakukan pelayanan kepada masyarakat pada pembuatan Dinas Kependudukan dan Catatan Sipil, dengan pertanyaan tersebut responden menjawam sebagai mana dapat dilihat pada tabel berikut ini:

TABEL 4-5

TINGKAT KEANDALAN PEGAWAI

\begin{tabular}{|c|l|c|c|}
\hline No & \multicolumn{1}{|c|}{ Uraian } & Jumlah & $\%$ \\
\hline 1. & Setuju & 12 & 60.0 \\
2. & Netral & 2 & 10.0 \\
3. & Kurang Setuju & 6 & 30.0 \\
& & & \\
\hline \multicolumn{2}{|c|}{ Jumlah } & 20 & 100.0 \\
\hline
\end{tabular}

Sumber: data primer (diolah), 2017.

Dari pernyataan korespenden terhadap tingkat kemampuan pegawai pada Dinas Kependudukan dan Catatan Sipil Kabupaten Pidie dalam memberikan pelayanan kepada masyarakat dalam pembuatan KTP dan KK dengan tepat dan terpecaya dimana masyarakat yang menjawab setuju tingkat kemampuan pegawai dalam memberikan pelayanan adalah 12 orang atau $60.0 \%$, dan yang menjawab netral adalah 2 orang responden atau $10.0 \%$ dan yang menjawab kurang setuju atau tidak ada kemampuan pegawai dalam pelayanan adalah responden menjawab 6 orang atau $30.0 \%$, dengan demikian bahwa dapat dilihat bahwa responden menilai tingkat kemampuan pegawai dalam memberikan pelayanan kepada masyarakat sudah baik.

\section{Tingkat Ketanggapan (responsiviness) pegawai.}

Ketanggapan (responsiviness) pegawai disini dilihat dari kemampuan pegawai untuk membantu masyarakat dan memberikan pelayanan dengan cepat atau adanya respek kepada masyarakat untuk menolong pembuatan KTP dan KK dan dan ketersediaan untuk melayani masayarakat dengan baik. untuk melihat tingkat ketanggapan yang diberikan adalah dari pernyataan responden dalam menjawab angket yang diberikan, dari angket yang diperoleh dari 50 responden dapat dilihat pada tabel dibawah ini; 
TABEL 4-6

TINGKAT KETANGGAPAN PEGAWAI

\begin{tabular}{|c|l|c|c|}
\hline No & \multicolumn{1}{|c|}{ Uraian } & Jumlah & $\%$ \\
\hline 1. & Setuju & 11 & 55.0 \\
2. & Netral & 2 & 10.0 \\
3. & Kurang Setuju & 7 & 35.0 \\
\hline \multicolumn{2}{|c|}{ Jumlah } & 20 & 100.0 \\
\hline
\end{tabular}

Sumber: data primer (diolah), 2017.

Dari pernyataan korespenden terhadap tingkat Ketanggapan (responsiviness) pegawai pada Dinas Kependudukan dan Catatan Sipil Kabupaten Pidie dalam memberikan pelayanan kepada masyarakat dalam pembuatan KTP dan KK yaitu kemampuan pegawai dalam membantu dan memberikan pelayanan yang cepat (responsif) dan tapat pada masyarakat dan memberikan informasi yang jelas, membiarkan masyarakat menunggu terlalu lama akan memberikan persepsi negative dalam kualitas pelayanan.

Dari pernyataan responden dan dapat diperoleh data bahwa masyarakat yang menjawab setuju dengan tingkat tanggapan pegawai pada masyarakat pembuat KTP dan KK adalah 11 orang atau $55.0 \%$, dan yang menjawab netral adalah 2 orang responden atau $10.0 \%$ dan yang menjawab kurang setuju atau tidak ada responsif pegawai dalam pelayanan adalah responden menjawab 7 orang atau $35.0 \%$, dengan demikian bahwa dapat dilihat bahwa responden menilai tingkat kemampuan responsive pegawai dalam memberikan pelayanan kepada masyarakat sudah baik.

\section{Bukti Langsung (tangible).}

Bukti langsung (tangible) adalah kemampuan pegawai dalam melakukan pekerjaan terhadap pelayanan kepada masyarakat dalam pembuatan KTP dan KK yaitu dilihat dari bukti fisik, peralatan personil dan media komunikasi, dimana pada kantor Dinas Kependudukan dan Catatan Sipil Kabupaten Pidie dilengkapi dengan pengeras suara dan juga pegawai menyampaikan informasi dengan baik dan sangat komunikatif, alam hal ini pernyataan responden terhadap kemampuan dalam bukti langsung dalam pelayanan yang diberikan oleh aparatur Dinas
Kependudukan dan Catatan Sipil Kabupaten Pidie, dapat dilihat pada tabel dibawah ini;

TABEL 4-7

TINGKAT BUKTI LANGSUNG

\begin{tabular}{|c|l|c|c|}
\hline No & \multicolumn{1}{|c|}{ Uraian } & Jumlah & $\%$ \\
\hline 1. & Setuju & 14 & 70.0 \\
2. & Netral & 2 & 10.0 \\
3. & Kurang Setuju & 4 & 20.0 \\
\hline \multicolumn{2}{r|}{ Jumlah } & 20 & 100.0 \\
\hline
\end{tabular}

Sumber: data primer (diolah), 2017.

Dari pernyataan korespenden pada bukti langsung (tangible) dalam pelayanan oleh pegawai pada Dinas Kependudukan dan Catatan Sipil Kabupaten Pidie kepada masyarakat dalam pembuatan KTP dan KK yaitu meliputi fasilitas fisik, perlengkapan dan sarana komunikasi pegawai dalam membantu dan memberikan pelayanan yang cepat (responsif) dan tapat pada masyarakat dan memberikan informasi yang jelas.

Dari pernyataan responden dan dapat diperoleh data bahwa masyarakat yang menjawab setuju dengan bukti langsung terhadap pelayanan pegawai pada masyarakat pembuat KTP dan KK adalah 14 orang atau $70.0 \%$, dan yang menjawab netral adalah 2 orang responden atau $10.0 \%$ dan yang menjawab kurang setuju atau tidak ada bukti langsung terhadap pegawai dalam pelayanan adalah responden menjawab 4 orang atau $20.0 \%$, dengan demikian bahwa dapat dilihat bahwa responden menilai tingkat bukti langsung terhadap pelayanan kepada masyarakat sudah baik.

\section{Kemampuan (Competence).}

Kemampuan (competence) adalah tingkat pengetahuan pegawai dalam dalam memahami keinginan masyarakat, tingkat kemampuan pegawai dilihat dari kemampuan dalam mempergunakan peralatan kantor seperti computer, mempergunakan jaringan online dalam perekaman data kependudukan dan juga kemampuan dalam memberikan solusi terhadap penyelesaian masalah yang berkaitan dengan pekerjaannya, untuk mengukur tingkat kemampuan pegawai dapat dilihat dari jawaban angket responden dalam tabel berikut ini: 
TABEL 4-8

TINGKAT KEMAMPUAN (COMPETENCE) PEGAWAI

\begin{tabular}{|c|l|c|c|}
\hline No & \multicolumn{1}{|c|}{ Uraian } & Jumlah & $\%$ \\
\hline 1. & Setuju & 13 & 65.0 \\
2. & Netral & 3 & 15.0 \\
3. & Kurang Setuju & 4 & 20.0 \\
\hline \multicolumn{2}{|c|}{ Jumlah } & 50 & 100.0 \\
\hline
\end{tabular}

Sumber: data primer (diolah), 2017.

Dari data yang diperoleh responden dalam penelitian ini penulis melihat bahwa responden menjawab setuju dengan tingkat kemampuan pegawai dalam pelayanan masyarakat dalam pembuatan KTP dan KK sebagaimana tersebut di atas adalah responden menjawab setuju dengan 13 orang atau $65.0 \%$, dan responden menjawab netral sejumlah 3 orang atau $15.0 \%$, sedangkan responden yang menjawab kurang setuju sejumlah 4 orang atau $20.0 \%$, dengan demikian dapat diasumsikan bawah tingka kompetensi pegawai dalam pelayanan pada Dinas Kependudukan dan Catatan Sipil Kabupaten Pidie sudah bagus.

\section{Tingkat Keramahan Pegawai.}

Keramahan merupakan sifat sopan santun pegawai dalam dalam menghadapi masyarakat, dimana sifat murah senyum, dapat menekan emosi, berlaku sopan, komunikatif, dan juga sifat-sifat yang dapat memberikan kepuasan atau kesan yang baik bagi masyarakat yang ingin membuat KTP dan KK, dalam hal ini masyarakat menilai tingkat keramahan pegawai dari jawaban angket yang diberikan hasilnya sebagaimana dapat dilihat pada tabel dibawah in:

TABEL 4-9

TINGKAT KERAMAHAN PEGAWAI

\begin{tabular}{|c|l|c|c|}
\hline No & \multicolumn{1}{|c|}{ Uraian } & Jumlah & $\%$ \\
\hline 1. & Setuju & 13 & 65.0 \\
2. & Netral & 4 & 20.0 \\
3. & Kurang Setuju & 3 & 15.0 \\
\hline \multicolumn{2}{|c|}{ Jumlah } & 20 & 100.0 \\
\hline
\end{tabular}

Sumber: data primer (diolah), 2017.

\section{Tingkat Keamanan Masyarakat.}

Jaminan (security) adalah jaminan keamanan bagi masyarakat, baik keamanan terhadap kenderaan bermotor maupun keamanan lainnya seperti adanya perampisan, pencopetan yang terjadi dilingkungan kantor, mengingat kantor Dinas Kependudukan dan Catatan Sipil Kabupaten Pidie terletak jauh dari tingkat meramaian kota tapi terletak pada kawasan kantor pemerintah, maka tingkat kerawanan kerhadap kriminalitas berkurang, namun demikian tidak ada kemungkinan akan terjadi pencurian seperti sebeda motor, dari hasil survey melihat bahwa keamanan sudah bisa dikatakan baik, namun hal ini perlu dibuktikan dengan kepuasan responden dalam pernyataan keamanan di sekitar lingkungan kantor Dinas Kependudukan dan Catatan Sipil Kabupaten Pidie, dari olahan data tersebut pada tabel 4-10 dapat diperoleh hasil adalah dimana responden yang menjawab setuju dengan tingkat keamanan kantor Dinas Kependudukan dan Catatan Sipil Kabupaten Pidie sebesar 14 orang atau $70.0 \%$ sedangkan yang menjawab netral sejumlah 4 orang responden atau $20.0 \%$, sedangkan yang menjawab kurang setuju berjumlah 2 orang atau $10.0 \%$, sebagaimana terlihat pada tabel berikut ini:

TABEL 4-10

TINGKAT KEAMANAN

\begin{tabular}{|c|l|c|c|}
\hline No & \multicolumn{1}{|c|}{ Uraian } & Jumlah & $\%$ \\
\hline 1. & Setuju & 14 & 70.0 \\
2. & Netral & 4 & 20.0 \\
3. & Kurang Setuju & 2 & 10.0 \\
\hline \multicolumn{2}{|c|}{ Jumlah } & 20 & 100.0 \\
\hline
\end{tabular}

Sumber: data primer (diolah), 2017.

Dari hasil tabel tersebut dapat diasumsikan bahwa tingkat keamanan pada kantor Dinas Kependudukan dan Catatan Sipil Kabupaten Pidie dari hasil data responden yang diuji bahwa keamanan sudah dikatakan baik.

\section{Tingkat Komunikasi.}

Komunikasi adalah kemampuan pegawai dalam mengjalin hubungan yang harmonis dengan masyarakat secara baik, benar dan menyakinkan, pegawai harus memahami keinginan public, dan perlu diajak untuk saling pengertian antara kedua belah pihak secara 
komunikasi yang baik dan benar, penyampaian informasi yang tepat agar masyarakat yang datang ke kantor Dinas Kependudukan dan Catatan Sipil Kabupaten Pidie merasa puas dan memberikan kesan yang menyenangkan, sehingga kantor tersebut dapat memberikan kesejukan dan adanya saling pengertian antara yang dilayani dengan pelayan itu sendiri.

Dalam penelitian ini responden akan memberikan penilaian pada tingkat komunikasi pegawai dengan masyarakat adalah tergambar pada table berikut ini:

TABEL 4-11

TINGKAT KOMONIKASI

\begin{tabular}{|c|l|c|c|}
\hline No & \multicolumn{1}{|c|}{ Uraian } & Jumlah & $\%$ \\
\hline 1. & Setuju & 15 & 75.0 \\
2. & Netral & 3 & 15.0 \\
3. & Kurang Setuju & 2 & 10.0 \\
\hline & Jumlah & 20 & 100.0 \\
\hline
\end{tabular}

Sumber: data primer (diolah), 2017.

Dari data yang diperoleh responden dalam penelitian ini penulis melihat bahwa responden menjawab setuju dengan tingkat keamanan masyarakat terhadap pelayanan dalam pembuatan KTP dan KK sebagaimana tersebut di atas adalah responden menjawab setuju dengan 15 orang atau $75.0 \%$, dan responden menjawab netral sejumlah 3 orang atau $15.0 \%$, sedangkan responden yang menjawab kurang setuju sejumlah 2 orang atau $10.0 \%$, dengan demikian dapat diasumsikan bawah tingka keamanan pada kantor pelayanan public Dinas Kependudukan dan Catatan Sipil Kabupaten Pidie dalam melayani masyarakat sudah baik.

\section{Tingkat Kepuasan Publik.}

Untuk mengetahui tingkat kepuasan public (masyarakat) pada Dinas Kependudukan dan Catatan Sipil Kabupaten Pidie dalam pelayanan pembuatan KTP dan KK, maka apabilan masyarakat terpenuhi apa yang diinginkan yang menjadi haknya masyarakat pada pelayanan public.

Pemenuhan kebutuhan masyarakat merupakan suatu kewajiban bagi aparatur public dalam pelayanan, public mempunyai harapan dan kebutuhan yang diinginkan, dikarenakan kebutuhan tersebut masyarakat akan menyampaikan kepada pihak yang berwenang untuk mengeluarkan atau mengurusnya, KTP dan KK bagi masyarakat adalah salah satu kebutuhan yang sangat mendesak atau kebutuhan primer (pokok) karena dengan tidak ada KTP dan KK tidak mendapat pelayanan kesehatan dan pelayanan lainnya, maka sangat diperlukan bagi kantor pelayanan public untuk mengerluarkan KTP dan KK bagi penduduknya. Dari salah satu responden yang diwawancara menyebutkan bahwa:

Bila KTP dan KK ini tidak dibutukan dalam segala pengurusan untuk pelayanan lainnya seperti kesehatan dan pendidikan dan juga lainnya, sunggung kami yang jauh tidak akan datang ke kantor Dinas Kependudukan dan Catatan Sipil Kabupaten Pidie ini untuk mengurus KTP dan KK tersebut biar kami tunggu saja pak keuchik yang bawa pulang dari kantor kecamatan, karena ini berupakan suatu kebutuhan kami sama dengan yang lainnya makan dan minum, maka kami ingin mengurusnya dengan cepat dan harus ada, (Masyarakat Pembuat KTP, : 12 Juli 2017)

Dari hasil wawancara tersebut dapat dianalogikan bahwa ternyata KTP KK sekarang ini sudah merupakan kebutuhan yang sangat mendesak perlu didapatkannya, makin maju suatu negara, kebutuhan identitas seorang warga dan keluarga semakin dibutuhkan, karena dengan teknologi sekarang semua data sudah terintegrasikan dalam suatu data base pemerintah, misalnya seorang tidak ada NIK dalam data kependudukan maka mereka tidak dapat memperoleh pelayanan kesehatan.

Dalam proses pencapaian pembutan KTP dan KK nilai terhadap kebutuhan akan KTP dan KK tersebut, penulis akan mewawancara dengan Kepala Dinas Kependudukan dan Catatan Sipil Kabupaten Pidie;

Bahwa dalam pembuatan KTP dan KK masyarakat sudah diwajibkan untuk mengurusnya ke kantor Dinas Kependudukan dan Catatan Sipil Kabupaten Pidie melalui kantor camat masing-masing dan ini secara umum dulu sudah ada perekaman data secara menyeluruh dalam Kabupaten ini, dan yang sekarang pembuatan KTP dan KK ada KTP yang belum keluar karena blangko KTP tidak ada ada juga masyarakat kita yang sudah wajib KTP atau KTP pemula dan KK baru ini yang akan diurus kesini, dan menyangkut dengan nilai selembar KTP dan KK sangat besar karena kalau KTP hilang ini proses pembuatan sangat rumit harus melului proses pembuatan surat kehilangan pada kepolisian dan kita lihat kembali data NIKnya kemudian dikeluarkan kembali KTP, yang sangat bernilai adalah NIK tersebut karena NIK ini kemana saja kita tinggal NIK ini sama tidak berubah, karena tiap penduduk Indonesia sudah terekam NIKnya dalam data base Kantor Kementrian Dalam Negeri di Jakarta, dan bila NIK tidak ada maka proses apapun yang menyangkut dengan pelayanan pemerintah tidak dapat diproses, 
misalnya pelayanan BPJS (berobat) tidak bisa dilayani dan tidak bisa di kleim pembayaran oleh asuransi BPJS maka terpaksa sipasien membayar jasa pelayanan kesehatan, maka nilai KTP dan KK tersebut sangat besar. (Kepala Dinas Kependudukan dan Catatan Sipli, 12 Juli 2017)

Dari hasil penjelasan Kepala Dinas Pelayanan pembuatan KTP dan KK pada kantor Dinas Kependudukan dan Catatan Sipil Kabupaten Pidie ternyata nilai selembar KTP dan KK bagi masyarakat sangat besar maknanya disamping proses pembuatannya butuh waktu yang panjang atau prosesdur pembuatan yang panjang juga waktu yang dibutuhkan juga panjang.

Dari hasil beberapa wawancara dengan pihak yang bisa memberikan informasi yang menyangkut dengan focus penelitian yang sedang dilakukan, bahwa pelayanan pembutan KTP dan KK bagi masyarakat sudah menujukan hal yang positif artinya masyarakat sudah merasa puas dengan pelayanan yang diberikan dengan system pengantrian dan dana yang dimintapun sudah stranparan sesuai dengan peraturan yang berlaku, serta tidak ada lagi calo dalam pembuatan KTP dan KK.

\section{Pembuktian Hipotesis.}

Dari hasil pengolahan data yang didapatkan melalui observasi dilapangan dan wawancara pada kualitas pelayanan terhadap kepuasan bagi masyarakat dalam pembuatan KTP dan KK pada kantor Dinas Kependudukan dan Catatan Sipil Kabupaten Pidie, dan dari perolehan data hasil jawaban responden dan wawancara dari semua pihak yang berhubungan dengan proses pelayanan pembuatan KTP dan KK, maka dalam penulisan ini dapat dilakukan pembuktian hipotesis yang bahwa kualitas pelayanan terhdap kepuasan masyarakat (public) dalam pembuatan KTP dan KK pada Kantor Dinas Kependudukan dan Catatan Sipil Kabupaten Pidie sudah sangat baik dan sesuai dengan prinsip-prinsip pelayanan publik.

\section{KESIMPULAN}

Adapun kesimpulan dalam penulisan ini antara lain sebagai berikut:

1. Kualitas pelayanan terhadap kupuasan Publik dalam pembuatan KTP dan KK pada Dinas Kependudukan dan Catatan
Sipil Kebupaten Pidie dilihat dari beberapa aspek tingkat kehandalan pegawai, tingkat ketanggapan pegawai, Bukti langsung, Kemampuan pegawai, tingkat keramahan pegawai, tingkat keamanan masyarakat, tingkat komunikasi, menujukan bahwa kualitas pelayanan sudah baik;

2. Dilihat dari tingkat kepuasan public (masyarakat) adalah pada pemenuhan kebutuhan, pencapaian nilai, keadilan menujukan bahwa pelayanan yang diberikan Dinas Kependudukan dan Catatan Sipil Kebupaten Pidie sangan puas.

3. Adapun faktor hambatan dalam memberikan pelayanan kepada masyarakat yang membuthkan KTP maupun KK pada Dinas Kependudukan dan Catatan Sipil Kebupaten Pidie adalah kurangnya fasilitas seperti peralatan computer, tidak adanya blangko KTP selama ini yang pengadaannya datang dari Jakarta, sumber daya manusia yang kurang kompetensi, maka pegawainya banyak yang pegawai kontrak, fasilitas gedung yang belum mempunyai standar.

\section{Saran.}

Adapun yang menjadi saran dalam penulisan ini yaitu :

1. Agar dapat memberikan kenyamanan bagi masyarakat dalam pembuatan KTP dan $\mathrm{KK}$ atau pengurusan lainnya, hendaknya pemerintah dapat memperbaiki atau membuat gedung yang layak dan sesuai dengan standar;

2. Pemerintah perlu mengusahan dimana balngko KTP yang sering kosong ini perlu diantisipasi segera dengan mengkoordinasi dengan pemerintah pusat;

3. Perlunya penambahan operator dalam memberikan pelayanan public, operator yang kompetensi dapat diandalkan;

4. Kepala dinas perlu mengupayakan lingkungan kontor yang bersih dan baik, serta pelayanan yang diberikan akan nyaman dan menyenangkan 